\title{
KERAGAMAN DAN ANALISIS KEKERABATAN 30 JENIS BEGONIA BERDASARKAN KARAKTER MORFOLOGI
}

\section{Diversity and relationship analysis of 30 species of Begonia based on morphological characters}

\author{
Sri Wahyuni*, Hartutiningsih-M. Siregar \\ Pusat Penelitian Konservasi Tumbuhan dan Kebun Raya - LIPI \\ Jl. Ir. H. Juanda No.13 Kota Bogor, Jawa Barat, Indonesia 16003 \\ *Email: sriwahyuni.krbogor@gmail.com
}

Diterima/Received: 10 Maret 2020; Disetujui/Accepted: 26 Juni 2020

\begin{abstract}
The living collection of Begonia in the Bogor Botanic Gardens has been used in hybridization to produce new varieties. This study aimed to describe the morphological characters, diversity, and relationship between species. The research was arranged in a randomized complete design with three replications. Observations included 39 qualitative and eight quantitative variables. Differences between species were tested using the $\mathrm{F}$ test at $5 \%$ and $1 \%$ significance level, followed by Duncan's Multiple Range tests. The relationship between genotypes were analyzed using cluster analysis, and principal component analysis by SPSS version 23. Analysis of variance showed that species significantly affected all quantitative characters. Principal components analysis on 30 Begonia species showed four components with initial eigenvalues $>1$. This value obtained from the reduction of 13 variables, and explained $65.50 \%$ diversity. Cluster analysis showed that the 30 Begonia species were clustered into six groups. The Begonia breeding program at Bogor Botanic Gardens referred to the classification of Begonias with ornamental foliage. Begonia species recommended for use for further breeding program are $B$. holocericeoides, B. kudoensis, and B. rex from group I; B. puspitae from group II; B. coriacea from group V; and B. masoniana from group VI.
\end{abstract}

Keywords: Begonia, cluster analysis, principal component analysis

\begin{abstract}
Abstrak
Koleksi Begonia di Kebun Raya Bogor (KRB) telah dimanfaatkan pada kegiatan hibridisasi untuk menghasilkan varietas baru. Penelitian ini bertujuan untuk memperoleh deskripsi karakter morfologi, keragaman morfologi, dan pola kekerabatan antar jenis Begonia. Bahan yang digunakan adalah 30 jenis Begonia koleksi KRB. Rancangan penelitian menggunakan rancangan acak lengkap dengan tiga ulangan. Peubah yang diamati sebanyak 39 peubah kualitatif dan delapan peubah kuantitatif. Perbedaan antara jenis diuji menggunakan uji F pada taraf nyata $5 \%$, dilanjutkan dengan uji lanjut Duncan's Multiple Range test. Keragaman dan pola hubungan kekerabatan dianalisis dengan analisis gerombol dan analisis komponen utama menggunakan software SPSS versi 23 . Hasil analisis ragam menunjukkan bahwa jenis Begonia berpengaruh nyata pada semua karakter peubah kuantitatif. Hasil analisis komponen utama pada 30 jenis Begonia terdapat empat komponen yang mempunyai akar ciri $>1$ yang merupakan hasil reduksi dari 13 peubah yang dapat menerangkan keragaman morfologi sebesar $65,50 \%$. Analisis gerombol menghasilkan dendrogram yang mengelompokkan Begonia koleksi KRB menjadi enam kelompok pada tingkat kemiripan 85\%. Program pemuliaan Begonia di KRB merujuk pada klasifikasi pemuliaan Begonia berdaun indah. Jenis Begonia yang direkomendasikan untuk digunakan dalam program pemuliaan selanjutnya yaitu B. holocericeoides, B. kudoensis, dan B. rex dari kelompok I; B. puspitae dari kelompok II; B. coriacea dari kelompok V; and B. masoniana dari kelompok VI.
\end{abstract}

Kata kunci: analisis gerombol, analisis komponen utama, Begonia 


\section{PENDAHULUAN}

Begonia (Begoniaceae) merupakan salah satu marga terbesar tumbuhan berbunga. Marga ini terdiri atas 1870 jenis yang diketahui tersebar di daerah subtropis dan tropis Afrika, Amerika, dan Asia (Moonlight et al. 2018). Benua Asia, khususnya kawasan Malesia merupakan pusat keragaman Begonia, yaitu sekitar 450 jenis, dan hampir setengahnya ditemukan di Indonesia (Kiew 2005; Girmansyah 2008; Hughes 2008; Hughes et al. 2009; Thomas et al. 2012). Begonia termasuk tumbuhan yang mudah dikenali, karena mempunyai ciri-ciri spesifik yaitu berupa terna tegak, semak atau menjalar, dengan batang yang berair, dan helaian daun yang tidak simetris (begoniifolia) (Tebbitt 2005; Dewitte et al. 2011).

Sampai tahun 2019 Kebun Raya Bogor (KRB) telah berhasil mengkoleksi 124 jenis Begonia yang terdiri atas 31 Begonia eksotik dan 93 jenis Begonia alam. Begonia alam diperoleh dari hasil eksplorasi tumbuhan ke seluruh wilayah hutan di Indonesia. Begonia eksotik adalah Begonia yang telah dikenal dan banyak dibudidayakan secara luas oleh hobiis dan pecinta tanaman hias (Siregar \& Siregar 2013).

Upaya konservasi Begonia yang terkelola dengan baik sangat penting dilakukan. Berbagai aktivitas manusia telah menimbulkan ancaman serius terhadap kelangsungan jenis-jenis dari marga ini. Ancaman utama terhadap kelangsungan hidup Begonia adalah penurunan dan pengurangan kualitas habitat alami, akibat tingginya aktivitas konversi hutan dan penebangan ilegal. Dari jenisjenis Begonia yang ada di dunia, terdapat satu jenis yang berasal dari Malaysia yang diyakini telah punah di habitat alam akibat alih fungsi lahan, yaitu B. eiromischa Ridl. Beberapa jenis lain termasuk ke dalam kategori langka, yaitu B. socotrana Hook.f. dan B. samhaensis M.Hughes \& A.G.Mill. dari Pulau Socotra, Yaman (Lucas \& Synge 1978; Hughes \& Miller 2002). Oleh karena itu, konservasi Begonia perlu dilakukan. Marga ini telah dapat menjadi salah satu kelompok takson prioritas utama konservasi tumbuhan di Indonesia, sebab: (1) tingkat endemisitasnya tinggi; (2) dapat direintroduksi ke alam; (3) berpotensi untuk dikonservasi secara ex situ; dan (4) bernilai ekonomi sebagai tanaman hias karena keunikan dan keindahan daunnya.
Budidaya dan pemuliaan Begonia telah banyak dilakukan di Indonesia. Salah satu varietas baru yang berhasil dirakit dan telah mendapat sertifikat Hak PVT adalah Begonia Lovely Jo, yang merupakan hasil persilangan interspesifik antara B. puspitae Ardi \& B. pasamanesis M.Hughes (Siregar \& Ardi 2015). Varietas-varietas baru lainnya akan dirakit dengan menggunakan koleksi jenisjenis Begonia yang ada di Kebun Raya Bogor (KRB). Kendala dalam perakitan varietas baru adalah terbatasnya informasi mengenai pewarisan sifat ciri, baik ciri-ciri kuantitatif maupun kualitatif. Hibridisasi telah digunakan secara luas pada Begonia untuk memperbaiki karakter pada bunga dan daun. Di negara-negara subtropis, hibridisasi interspesifik dilakukan pada Begonia untuk mendapatkan kultivar baru dengan sifat-sifat agronomi penting seperti: (1) kemampuan berbunga pada musim dingin; (2) bentuk dan warna bunga dan daun yang baru; dan (3) ketahanan terhadap hama dan penyakit (Kroon 1993; Horn 2004; Ciolakowska et al. 2010; Chen \& Mii 2012).

Para pemulia mempunyai kecenderungan yang berbeda-beda dalam memuliakan tanaman hias. Pada umumnya, kombinasi sifat-sifat karakter yang dituju tergantung dari permintaan pasar. Usaha pemuliaan tanaman hias Begonia di Eropa yang telah berlangsung cukup lama, sehingga memungkinkan para pemulia mengelompokkan Begonia budidaya berdasarkan sifat-sifat karakter yang dituju. Terkait dengan kegiatan pemuliaan Begonia, Hvoslef-Eide \& Munster (2006) mengklasifikasikan Begonia menjadi enam kelompok yaitu, (1) Begonia berbunga indah dan berumbi (Tuberous hybrid Begonias), dengan nama ilmiah Begonia $\times$ tuberhybrida Voss, jenis ini dikenal sebagai Begonia berbunga di musim panas (summer-flowering begonias); (2) Loraine Begonia (B. socotrana Hook.f. $\times$ B. dregei Otto \& Dietr.), dengan nama ilmiah $B$. $\times$ cheimantha Everett ex C.Weber; tanaman hibrid ini dikenal dengan Scandinavian-Norwegian atau Christmas Begonia, dan termasuk ke dalam kelolompok Begonia berbunga di musim dingin; (3) Elatior Begonia (B. socotrana $\times$ tuberous hybrid), dengan nama ilmiah Begonia $\times$ hiemalis Fotsch; tanaman ini dikenal sebagai Begonia musim gugur dan termasuk dalam kelompok Begonia musim dingin; (4) Semperflorens Begonia (B. cucullata Willd. $x$ B. cheimantha) dengan nama ilmiah 
B. semperflorens cultorum. Kelompok ini juga disebut dengan nama 'Semperflorens gracilis' (Eropa) dan 'Wax begonias' (USA); (5) Begonia berdaun indah (Begonias with ornamental foliage), yang beranggotakan kultivar $B$. rex Putz. (B. rex cultorum, B. masoniana (B. 'Iron Cross') dan jenisjenis hibrid Meksiko lainnya; dan (6) Kelompok lainnya, yaitu kelompok yang tidak termasuk dalam kategori di atas.

Informasi keragaman genetik sangat mempengaruhi keberhasilan suatu kegiatan pemuliaan (Sleper \& PoehIman 2006). Keberhasilan program pemuliaan ditentukan oleh pemilihan materi bahan tetua yang akan digunakan, karakter dan pewarisan karakter yang akan dikembangkan serta identifikasi keberadaan sumber-sumber plasma nutfah yang membawa karakter yang dituju (Syukur et al. 2012). Informasi karakter-karakter yang dimiliki dari setiap genotipe koleksi plasma nutfah dan hubungan kekerabatan dapat digunakan sebagai dasar dalam rekomendasi tetua yang akan dipilih pada pembentukan populasi dalam program pemuliaan terutama dalam studi pewarisan sifat. Hal ini juga penting bagi kegiatan konservasi dan pemanfaatan plasma nutfah secara berkelanjutan.

Penelitian tentang hubungan kekerabatan Begonia telah banyak dilakukan oleh para peneliti terutama untuk klasifikasi Begonia secara taksonomi berdasarkan keragaman morfologi dan molekular (Rajbhandary et al. 2011; Chung et al. 2014; Harrison et al. 2016; Moonlight et al. 2018). Penelitian ini bertujuan untuk memperoleh deskripsi karakter morfologi, keragaman morfologi dan pola kekerabatan antar jenis Begonia. Hasil penelitian dapat digunakan untuk melihat perbedaan yang signifikan untuk perakitan varietas baru.

\section{BAHAN DAN METODE}

Penelitian dilakukan mulai bulan Mei sampai Oktober 2019 di Rumah Kaca Pembibitan Gedung IX, Pusat Penelitian Konservasi Tumbuhan dan Kebun Raya-LIPI. Bahan yang digunakan adalah 30 jenis Begonia koleksi KRB hasil dari eksplorasi ke berbagai wilayah di Indonesia dan beberapa koleksi sumbangan (Tabel 1). Percobaan disusun dalam rancangan acak lengkap faktor tunggal (jenis Begonia) dengan tiga ulangan. Setiap satuan percobaan terdiri atas tiga pot, dan masing-masing pot terdapat satu tanaman.

\section{Pengamatan morfologi}

Peubah yang diamati adalah peubah kuantitatif dan peubah kualitatif. Peubah kuantitatif meliputi tinggi tanaman $(\mathrm{cm})$, diameter batang $(\mathrm{mm})$, lebar tajuk $(\mathrm{cm})$, panjang daun $(\mathrm{cm})$, lebar daun $(\mathrm{cm})$, tebal daun $(\mathrm{mm})$, panjang tangkai daun $(\mathrm{cm})$, dan diameter tangkai daun $(\mathrm{mm})$. Peubah kualitatif yang diamati sebanyak 39 peubah berdasarkan Panduan Pelaksanaan Uji (PPU) BUSS Kebaruan, Keunikan, Keseragaman dan Kestabilan Begonia (UPOV 2007; Kementerian Pertanian Republik Indonesia 2014).

\section{Analisis data}

Data keragaman morfologi 30 jenis Begonia diuji dengan menggunakan uji $\mathrm{F}$ pada taraf nyata $5 \%$ dan $1 \%$. Jika terdapat perbedaan yang nyata, maka untuk mengetahui jenis yang berpenampilan lebih baik dilanjutkan dengan uji lanjut DMRT (Duncan's Multilpe Range Test). Sidik ragam yang digunakan dalam penelitian ini berdasarkan Mattjik \& Sumertajaya (2006). Keragaman morfologi dan pola hubungan kekerabatan dianalisis dengan analisis komponen utama (AKU) dan analisis gerombol (Cluster analysis) menggunakan software SPSS versi 23.

Analisis gerombol termasuk dalam teknik analisis multivariate metode interdependen. Teknik ini bertujuan untuk mengatur informasi atau meringkas data dengan cara mengelompokkan objek-objek berdasarkan kesamaan karakteristik tertentu. Dengan demikian, analisis gerombol atau clustering memiliki tujuan untuk mengelompokkan data dari serangkaian pengamatan ke subset (disebut cluster). Pengelompokan ini didasarkan pada ukuran kemiripan menggunakan sebuah indeks dengan makna tertentu seperti jarak euclidean (akar ciri) atau jarak lain, sejenis indeks peluang, atau lainnya. Jarak akar ciri antar objek perlakuan akan menentukan kemiripan dari setiap objek perlakuan (Mattjik \& Sumertajaya 2011).

Ukuran jarak genetik (genetic distance) berdasarkan karakter fenotipe adalah salah satu teknik multivariat utama yang digunakan untuk memberikan kriteria untuk memilih tetua. Jarak genetik antara genotipe adalah cara untuk memprediksi variabilitas genetik di antara 
kombinasi hibrida. Alat utama yang digunakan dalam memperkirakan jarak genetik adalah analisis multivariate. Analisis ini memungkinkan untuk mengumpulkan banyak variabel menjadi satu. Analisis jarak mahalanobis $\left(D^{2}\right)$ dan jarak euclidean adalah prosedur statistik yang paling banyak digunakan untuk memperkirakan jarak genetik (Bertan et al. 2007). Analisis gerombol merupakan salah satu analisis yang dapat mengelompokkan objek perlakuan berdasarkan setiap data

Tabel 1. Koleksi Begonia di KRB yang diteliti pengamatannya ke dalam beberapa kelas (gerombol), sehingga setiap kelas terdiri atas objek perlakuan yang lebih homogen atau mirip (Yunianti et al. 2007; Bertan et al. 2007; Mattjik \& Sumertajaya 2011).

Informasi hubungan kekerabatan akan digunakan sebagai dasar dalam penentuan tetua yang akan dipilih dalam program perkawinan silang untuk menghasilkan hibrid baru Begonia.

\begin{tabular}{|c|c|c|c|}
\hline No & Nama jenis & Kolektor & Asal \\
\hline 1 & Begonia $\times$ argenteoguttata M.Lemoine & HT 39 & Argentina \\
\hline 2 & B. augustae Irmsch. & DW 1328 & Waigeo-Papua \\
\hline 3 & B. bipinnatifida J.J.Sm. & HT 88 & Papua \\
\hline 4 & B. brevirimosa subsp. exotica Tebbitt & Mr. 329 & Papua \\
\hline 5 & B. chloroneura P.Wilkie \& Sands & HT83 & Kalimantan \\
\hline 6 & B. coriacea Hassk & DM 1267 & Karangasem-Bali \\
\hline 7 & B. galeolepis Ardi \& D.C. Thomas & KRE & Seram-Maluku \\
\hline 8 & B. goegoensis N.E. Br & HT 16 & Sumatra \\
\hline 9 & B. handelii Irmsch. & HT 84 & Indochina \\
\hline 10 & B. holosericea (Teijs. \& Binn.) Teijs.\& Binn & YY 64 & Halmahera- Maluku \\
\hline 11 & B. holosericeoides Ardi \& D.C. Thomas & YY 137 & Halmahera- Maluku \\
\hline 12 & B. imperialis Lem. & HT 25 & Meksiko \\
\hline 13 & B. isoptera Dryand. ex Sm. & WA 11 & Taman Nasional Ujung Kulon Jawa \\
\hline 14 & B. kingiana Irmsch. & HT 86 & Semenanjung Malaya \\
\hline 15 & B. kudoensis Girm. & CP 66 & Sumatra Barat \\
\hline 16 & B. kui C.-I Peng & HT 85 & Vietnam \\
\hline 17 & B. lepida Blume & PW520 & Bodogol-Jawa \\
\hline 18 & B. longifolia Blume & HT 03 & Bogor-Jawa \\
\hline 19 & B. masoniana Irmsch. ex Ziesenh & HT 26 & China \\
\hline 20 & B. metallica W.G.Sm. & HT 31 & Brazil \\
\hline 21 & B. natunaensis C. W. Lin \& C.-I Peng & HT 16 & Sumatra Barat \\
\hline 22 & B. pasamanensis M. Hughes & TT972 & Sumatra Barat \\
\hline 23 & B. puspitae Ardi & DM 1742 & Sumatra Barat \\
\hline 24 & B. rachmatii Tebbitt & HT 17 & Sulawesi Selatan \\
\hline 25 & B. rex Putz & HT 45 & Assam-India \\
\hline 26 & B. sageaensis Wiriad. & YY 202 & Halmahera-Maluku \\
\hline 27 & B. sublobata Jack & CP 33 & Sumatra \\
\hline 28 & B. sudjanae C.-A.Jansson & HT 199 & Sumatra \\
\hline 29 & B. thelmae L.B.Sm. \& Wassh. & HT 50 & Brazil \\
\hline 30 & B. triginticolium Girm. & HT 87 & Taman Nasional Bukit Tiga Puluh-Sumatra \\
\hline
\end{tabular}

\section{HASIL DAN PEMBAHASAN}

\section{Keragaman karakter morfologi}

Hasil analisis ragam menunjukkan bahwa jenis Begonia berpengaruh nyata pada semua karakter kuantitatif yang diamati, yaitu tinggi tanaman, diameter batang, lebar tajuk, panjang daun, lebar daun, tebal daun, panjang tangkai daun, dan diameter tangkai daun (Tabel 2). Hal ini menunjukkan bahwa koleksi Begonia di KRB mempunyai keragaman karakter vegetatif. Keragaman karakter ini dapat dijadikan sumber tetua dalam program pemuliaan tanaman Begonia pada karakter yang akan diperbaiki atau kombinasi karakter baru, sehingga diperoleh varietas baru yang berbeda dari tetuanya. Sifat atau karakter tertentu yang ingin diperbaiki dapat berasal dari varietas lain, jenis liar yang sekerabat atau jenis lain. Ketersediaan keragaman genetik akan menentukan 
keberhasilan program pemuliaan (Yunianti et al. 2007).

Jenis-jenis yang menunjukkan karakter tertinggi dibandingkan dengan jenis lain ditunjukkan pada Tabel 3. Tanaman tertinggi ditunjukkan oleh Begonia $x$ argenteoguttata. Diameter batang terbesar ditunjukkan oleh $B . x$ argenteoguttata, B. masoniana, $B$. puspitae, dan $B$. sudjanae. Lebar tajuk terbesar ditunjukkan oleh B. $x$ argenteoguttata, B. longifolia, dan $B$. natunaensis. Daun terpanjang ditunjukkan oleh $B$. brevirimosa. Daun terlebar ditunjukkan oleh B. goegoensis. Daun paling tebal ditunjukkan oleh $B$. kingiana dan $B$. lepida. Tangkai daun terpanjang ditunjukkan oleh $B$. goegoensis. Diameter tangkai daun terbesar ditunjukkan oleh B. puspitae.

Hasil penelitian menunjukkan keragaman yang terdapat di antara 30 jenis koleksi KRB merupakan sumber plasma nutfah yang nantinya dapat digunakan sebagai sumber tetua dalam pemuliaan tanaman Begonia. Keragaman karakter- karakter kuantitatif ini akan dikombinasikan dengan karakter-karakter kualitatif seperti warna dan bentuk daun. Begonia yang sudah berhasil populer menjadi komoditi tanaman hias dan cukup digemari seperti $B$. brevirimosa dan B. imperialis dapat langsung dinikmati sebagai tanaman hias tanpa atau tidak melalui tahapan hibridisasi (Krempin 1993). Jenis-jenis ini mempunyai warna daun yang menarik, sehingga dapat digunakan sebagai tetua. Sedangkan jenis yang berdaun indah hasil eksplorasi dari hutan alam di Indonesia memerlukan proses adaptasi terlebih dahulu seperti B. bipinnatifida, B. chloroneura, $B$. holosericea, B. holosericeoides, dan B. goegoensis (Hughes \& Peng 2018). Mengingat keragaman koleksi jenis Begonia di KRB yang tersedia, maka program pemuliaan Begonia di KRB diarahkan pada jenis dataran rendah untuk pengembangan Begonia hias daun (Siregar et. al. 2015) sesuai dengan klasifikasi Begonia berdaun indah (Begonias with ornamental foliage).

Tabel 2. Kuadrat tengah karakter vegetatif Begonia

\begin{tabular}{lccccccccc}
\hline $\begin{array}{c}\text { Sumber } \\
\text { keragaman }\end{array}$ & $\mathbf{d b}$ & $\begin{array}{c}\text { Tinggi } \\
\mathbf{( \mathbf { c m } )}\end{array}$ & $\begin{array}{c}\text { Diameter } \\
\text { batang } \mathbf{( m m})\end{array}$ & $\begin{array}{c}\text { Lebar } \\
\text { tajuk }(\mathbf{c m})\end{array}$ & $\begin{array}{c}\text { Panjang } \\
\text { daun } \\
\mathbf{( c m})\end{array}$ & $\begin{array}{c}\text { Lebar } \\
\text { daun } \\
\mathbf{( c m})\end{array}$ & $\begin{array}{c}\text { Tebal } \\
\text { daun } \\
(\mathbf{m m})\end{array}$ & $\begin{array}{c}\text { Panjang } \\
\text { tangkai } \\
\text { daun }(\mathbf{c m})\end{array}$ & $\begin{array}{c}\text { Diameter } \\
\text { tangkai } \\
\text { daun }(\mathbf{m m})\end{array}$ \\
\hline Jenis & 29 & $3435,05^{* *}$ & $35,36^{* *}$ & $671,71^{* *}$ & $64,42^{* *}$ & $52,88^{* *}$ & $0,04^{* *}$ & $382,28^{* *}$ & $9,23^{* *}$ \\
Galat & 60 & 29,29 & 1,58 & 120,12 & 4,84 & 2,81 & 0,09 & 22,15 & 0,36 \\
\hline
\end{tabular}

Ket: ${ }^{* *}=$ berpengaruh nyata pada $\alpha 0.01$

Tabel 3. Nilai tengah peubah kuantitatif vegetatif pada Begonia

\begin{tabular}{|c|c|c|c|c|c|c|c|c|}
\hline Jenis & Tinggi (cm) & $\begin{array}{c}\text { Diameter } \\
\text { batang } \\
(\mathrm{mm})\end{array}$ & $\begin{array}{l}\text { Lebar Tajuk } \\
\qquad(\mathrm{cm})\end{array}$ & $\begin{array}{c}\text { Panjang } \\
\text { daun }(\mathrm{cm})\end{array}$ & $\begin{array}{l}\text { Lebar daun } \\
\qquad(\mathrm{cm})\end{array}$ & $\begin{array}{l}\text { Tebal } \\
\text { daun } \\
(\mathrm{mm})\end{array}$ & $\begin{array}{c}\text { Panjang } \\
\text { tangkai } \\
\text { daun }(\mathrm{cm})\end{array}$ & $\begin{array}{c}\text { Diameter } \\
\text { tangkai daun } \\
(\mathrm{mm})\end{array}$ \\
\hline $\begin{array}{l}\text { Begonia } x \\
\text { argenteoguttata }\end{array}$ & $179,00 \mathrm{a}$ & 14,11 a & $75,00 \mathrm{a}$ & $16,33 \mathrm{c}-\mathrm{g}$ & 5,00 hij & $0,31 b$ & $2,83 \mathrm{ji}$ & $25,63 \mathrm{hij}$ \\
\hline B. augustae & $63,33 d$ & $8,43 c-f$ & $46,33 \mathrm{~b}-\mathrm{e}$ & $16,26 \mathrm{c}-\mathrm{g}$ & 9,56 ef & $0,18 b$ & 3,1 ji & $25,27 \mathrm{hij}$ \\
\hline B. bipinnatifida & $26,67 \mathrm{~g}-\mathrm{k}$ & $8,37 c-f$ & $17,26 \mathrm{~h}-\mathrm{k}$ & $7,43 \mathrm{kl}$ & $6,16 \mathrm{gh}$ & $0,17 b$ & $2,50 \mathrm{ji}$ & 26,50 ghi \\
\hline B. brevirimosa & $72,67 c$ & $8,58 \mathrm{c}-\mathrm{f}$ & $30,66 \mathrm{e}-\mathrm{k}$ & 23,67 a & 11,76 cde & $0,22 b$ & 5,60 hij & $55,00 \mathrm{bc}$ \\
\hline B. chloroneura & $47,67 \mathrm{e}$ & $8,18 \mathrm{~d}-\mathrm{g}$ & $43,33 b-f$ & $15,56 \mathrm{c}-\mathrm{g}$ & $11,60 \mathrm{de}$ & $0,18 b$ & $31,67 b c$ & $53,17 \mathrm{bc}$ \\
\hline B. coriacea & $26,00 \mathrm{~g}-\mathrm{k}$ & 5,67 hij & $14,00 \mathrm{jk}$ & $9,26 \mathrm{jkl}$ & 8,50 efg & $0,28 b$ & 20,33 def & $35,43 \mathrm{e}-\mathrm{h}$ \\
\hline B. galeolepis & $23,63 \mathrm{~h}-\mathrm{I}$ & 5,91 hij & $37,00 \mathrm{c}-\mathrm{h}$ & $16,06 \mathrm{c}-\mathrm{g}$ & $13,86 \mathrm{bcd}$ & $0,2 b$ & $11,57 \mathrm{f}-\mathrm{i}$ & 35,53 e-h \\
\hline B. goegoensis & 42,67 ef & $10,12 \mathrm{bcd}$ & $55,33 \mathrm{bc}$ & 17,50 b-e & $19,00 \mathrm{a}$ & $0,28 b$ & 48,77 a & 40,93 def \\
\hline B. handelii & $14,33 \mathrm{~m}-\mathrm{o}$ & 5,04 hij & $30,33 d-k$ & $12,00 \mathrm{hij}$ & 9,00 efg & $0,23 b$ & $17,66 \mathrm{~d}-\mathrm{g}$ & 25,63 hij \\
\hline B. holosericea & $18,33 \mathrm{k}-\mathrm{o}$ & $6,39 \mathrm{f}-\mathrm{i}$ & $33,66 \mathrm{~d}-\mathrm{k}$ & $12,67 \mathrm{~g}-\mathrm{j}$ & 11,50 de & $0,25 b$ & $12,66 \mathrm{fgh}$ & $32,30 \mathrm{f}-\mathrm{i}$ \\
\hline B. holosericeoides & $17,17 \mathrm{k}-\mathrm{o}$ & 7,23 e-h & $29,33 d-k$ & $13,60 \mathrm{e}-\mathrm{i}$ & 10,10 ef & $0,22 b$ & $94,00 \mathrm{~g}-\mathrm{j}$ & $31,07 \mathrm{f}-\mathrm{i}$ \\
\hline B. imperialis & $12,33 \mathrm{mno}$ & 5,07 hij & $33,66 \mathrm{~d}-\mathrm{k}$ & 12,00 hij & 8,66 ef & $0,23 b$ & $22,33 \mathrm{de}$ & 25,56 hij \\
\hline B. isoptera & $60,67 d$ & $5,14 \mathrm{hij}$ & $21,66 \mathrm{f}-\mathrm{k}$ & $15,90 \mathrm{c}-\mathrm{g}$ & 7,11 efg & $0,24 b$ & 1,03 j & $24,83 \mathrm{hij}$ \\
\hline B. kingiana & $15,231-0$ & 5,32 b-e & $25,50 \mathrm{f}-\mathrm{k}$ & $10,90 \mathrm{ijk}$ & $7,10 \mathrm{fgh}$ & $0,74 a$ & $12,13 \mathrm{fgh}$ & $30,6 \mathrm{f}-\mathrm{i}$ \\
\hline B. kudoensis & 42,17 ef & 9,26 b-e & $49,33 \mathrm{bcd}$ & $19,50 \mathrm{bc}$ & $14,40 \mathrm{bcd}$ & $0,26 b$ & $17,33 \mathrm{~d}-\mathrm{g}$ & $61,73 \mathrm{~b}$ \\
\hline B. kui & $22,17 \mathrm{i}-\mathrm{m}$ & $11,04 \mathrm{~b}$ & $42,33 \mathrm{c}-\mathrm{g}$ & $14,77 d-i$ & $14,83 \mathrm{bc}$ & $0,30 \mathrm{~b}$ & 16,33 efg & $55,23 b c$ \\
\hline B. lepida & 31,33 ghi & 3,74 jk & $12,667 \mathrm{k}$ & $7,60 \mathrm{kl}$ & 4,03 hij & $0,67 a$ & $0,63 j$ & $0,93 \mathrm{k}$ \\
\hline B. longifolia & $110,67 b$ & $5,88 \mathrm{~g}-\mathrm{j}$ & $61,67 a$ & $17,33 \mathrm{~b}-\mathrm{e}$ & 11,23 de & $0,20 b$ & 10,70 ghi & $22,53 \mathrm{ij}$ \\
\hline B. masoniana & $29,67 \mathrm{gh}$ & 13,87 a & $29,33 d-k$ & $12,10 \mathrm{~g}-\mathrm{i}$ & $13,90 \mathrm{bcd}$ & $0,19 b$ & $17,66 \mathrm{~d}-\mathrm{g}$ & $46,667 \mathrm{~cd}$ \\
\hline B. metallica & $59,33 d$ & 5,08 hij & $50,33 \mathrm{bcd}$ & $16,33 \mathrm{c}-\mathrm{g}$ & 8,93 efg & $0,23 b$ & 10,90 ghi & 27,90 ghi \\
\hline
\end{tabular}




\begin{tabular}{|c|c|c|c|c|c|c|c|c|}
\hline Jenis & Tinggi (cm) & $\begin{array}{c}\text { Diameter } \\
\text { batang } \\
(\mathrm{mm})\end{array}$ & $\begin{array}{l}\text { Lebar Tajuk } \\
\text { (cm) }\end{array}$ & $\begin{array}{c}\text { Panjang } \\
\text { daun }(\mathrm{cm})\end{array}$ & $\begin{array}{l}\text { Lebar daun } \\
\text { (cm) }\end{array}$ & $\begin{array}{l}\text { Tebal } \\
\text { daun } \\
(\mathrm{mm})\end{array}$ & $\begin{array}{c}\text { Panjang } \\
\text { tangkai } \\
\text { daun }(\mathrm{cm})\end{array}$ & $\begin{array}{c}\text { Diameter } \\
\text { tangkai daun } \\
(\mathrm{mm})\end{array}$ \\
\hline B. natunaensis & $31,67 \mathrm{gh}$ & $10,38 \mathrm{bcd}$ & $62,67 a$ & 17,16 b-e & $14,00 \mathrm{bcd}$ & $0,28 b$ & $34,33 \mathrm{~b}$ & $58,10 \mathrm{~b}$ \\
\hline B. pasamanensis & 8,130 & $4,75 j$ & $15,67 \mathrm{ijk}$ & $7,43 \mathrm{kl}$ & 6,06 ghi & $0,22 b$ & $2,33 \mathrm{j}$ & $22,30 \mathrm{ij}$ \\
\hline B. puspitae & $33,93 \mathrm{fgh}$ & $15,79 a$ & $34,67 c-j$ & $16,76 c-f$ & 11,50 ed & $0,27 b$ & 23,66 cde & 81,87 a \\
\hline B. rachmatii & $33,00 \mathrm{fgh}$ & $2,20 \mathrm{k}$ & 20,67 g-k & 5,961 & 3,10 ij & $0,19 b$ & 4,13 hij & $0,58 \mathrm{k}$ \\
\hline B. rex & $28 g-j$ & 10,65 bc & 45,00 b-e & $21,20 a b$ & $14,40 \mathrm{bcd}$ & $0,25 b$ & $12,24 \mathrm{fgh}$ & $61,83 \mathrm{~b}$ \\
\hline B. sageaensis & 11,33 no & 5,74 hij & 28,67 e-k & 13,26 e-j & 9,83 ef & $0,28 b$ & 5,33 hij & 44,40 cde \\
\hline B. sublobata & $36,33 \mathrm{fg}$ & $11,37 \mathrm{~b}$ & $37,00 \mathrm{c}-\mathrm{i}$ & $16,83 c-f$ & $13,40 \mathrm{bcd}$ & $0,27 b$ & 16,56 efg & $37,63 \mathrm{~d}-\mathrm{g}$ \\
\hline B. sudjanae & 41,66 ef & $14,48 a$ & $37,00 c-i$ & $18,53 \mathrm{bcd}$ & $15,43 \mathrm{~b}$ & $0,24 b$ & $25,54 \mathrm{~cd}$ & 27,67 ghi \\
\hline B. thelmae & $47,66 \mathrm{e}$ & 7,3 e-h & $39 c-h$ & 5,331 & $2,50 \mathrm{j}$ & $0,23 b$ & 0,967 j & $14,50 \mathrm{jk}$ \\
\hline B. triginticolium & $33,66 \mathrm{fgh}$ & $7,06 \mathrm{e}-\mathrm{i}$ & $36,67 c-i$ & $7,83 \mathrm{kI}$ & $2,83 \mathrm{j}$ & $0,22 b$ & $1,10 \mathrm{j}$ & $14,33 \mathrm{jk}$ \\
\hline
\end{tabular}

Ket: Angka yang dikuti huruf yang sama pada kolom yang sama tidak berbeda nyata menurut DMRT taraf $5 \%$

\section{Analisis kekerabatan jenis Begonia}

Berdasarkan hasil uji normalitas data pada semua peubah yang digunakan, terdapat 16 peubah yang memenuhi asumsi dalam analisis faktor. Hasil analisis menunjukkan nilai Kaiser-Mayer-Olkin Measure of Sampling Adequacy (KMO MSA) >0,50 yaitu 0,583, uji Bartlett's Test of Sphericity (Sig)
$<0,05$ yaitu 0,000 (Tabel 4) dan terdapat 13 peubah yang menunjukkan hubungan atau korelasi yang kuat antar peubah yang ditunjukkan oleh nilai korelasi anti image matrik (Anti-image Correlation) antar variabel lebih besar dari 0,50 (Tabel 5), sehingga 13 peubah ini yang dianalisis lebih lanjut dalam analisis komponen utama.

Tabel 4. Hasil uji KMO dan Bartlett

\begin{tabular}{llr}
\hline \multicolumn{1}{c}{ Uji } & \multicolumn{1}{c}{ Nilai } \\
\hline Kaiser-Meyer-Olkin Measure of Sampling Adequacy. & & .583 \\
Bartlett's Test of Sphericity & Approx. Chi-Square & 183.249 \\
& df & 120 \\
& Sig. & .000 \\
\hline
\end{tabular}

Tabel 5. Nilai anti image matrik

\begin{tabular}{|c|c|c|c|c|c|c|c|c|c|c|c|c|c|c|c|c|c|}
\hline \multicolumn{18}{|c|}{ Anti-image Matrices } \\
\hline \multirow{16}{*}{$\begin{array}{l}\text { Anti- } \\
\text { image } \\
\text { Correlati } \\
\text { on }\end{array}$} & K2 & $.495^{\mathrm{a}}$ &,- 387 & ,221 &,- 348 & 195 & , 089 &,- 029 & 131 &,- 014 &,- 043 & ,094 & 035 &,- 231 &,- 030 & ,214 &,- 286 \\
\hline & K8 &,- 387 & $.599^{a}$ & ,084 & 100 &,- 107 & ,012 & ,014 &,- 025 & 130 & 020 &,- 143 & ,410 & 022 & 114 &,- 034 & 147 \\
\hline & K10 & 221 & 084 & $.605^{a}$ &,- 058 & ,031 & 132 &,- 242 & 059 & ,506 & 192 & 152 & 373 & ,263 & ,054 & ,090 &,- 115 \\
\hline & K11 &,- 348 & 100 &,- 058 & $.550^{\mathrm{a}}$ &,- 103 & ,012 & ,001 & ,012 &,- 127 &,- 177 & 138 &,- 359 & 298 & 195 &,- 016 &,- 074 \\
\hline & K13 & 195 &,- 107 & 031 &,- 103 & $.528^{\mathrm{a}}$ &,- 015 &,- 106 &,- 077 &,- 207 & 202 & ,244 &,- 034 & 014 & ,062 & 141 &,- 261 \\
\hline & K18 & 089, & ,012 & 132 & 012 &,- 015 & $.580^{a}$ & 050 &,- 575 & -124 &,- 064 &,- 476 & 181 & 136 & ,084 & 179, & 019, \\
\hline & K23 &,- 029 & 014 &,- 242 & 001 & -,106 & ,050 & $.603^{a}$ &,- 295 & 002 &,- 332 & ,044 &,- 373 &,- 202 &,- 078 &,- 286 & 286 \\
\hline & K26 & 131 &,- 025 & ,059 & 012 &,- 077 &,- 575 &,- 295 & $.673^{a}$ & 017 & -176 & 200 &,- 142 & -,091 &,- 062 & 109, &,- 226 \\
\hline & K28 &,- 014 & 130, & 506 & -127 &,- 207 & -124 & ,002 & 017 & $.463^{a}$ & 242 & ,023 & 258 &,- 020 & 081 &,- 049 & 081 \\
\hline & K29 &,- 043 & ,020 & 192 & -177 & 202 &,- 064 &,- 332 & -176 & 242 & $.600^{\mathrm{a}}$ &,- 035 & 384 &,- 087 & 035 & 148 &,- 130 \\
\hline & K31 & 094 & -143 & 152 & 138 & 244 &,- 476 & ,044 & 200 & ,023 &,- 035 & $.621^{a}$ & -209 & 169, &,- 357 &,- 286 & ,034 \\
\hline & K32 & ,035 & 410 & 373, & -,359 &,- 034 & 181 &,- 373 & -142 & 258 & 384 & -209 & $.477^{a}$ & ,011 & 020, & 142 &,- 037 \\
\hline & K33 &,- 231 & ,022 & 263 & 298 & 014 & 136 &,- 202 &,- 091 &,- 020 &,- 087 & 169, & 011 & $.738^{a}$ &,- 326 &,- 313 & 126 \\
\hline & K34 &,- 030 & 114 & ,054 & 195 & ,062 & ,084 &,- 078 &,- 062 & 081 & ,035 &,- 357 & ,020 &,- 326 & $.634^{a}$ & 474 &,- 467 \\
\hline & K37 & 214 &,- 034 & 090 &,- 016 & 141 & 179, &,- 286 & 109, &,- 049 & 148 &,- 286 & 142 &,- 313 & 474 & $.507^{a}$ &,- 844 \\
\hline & K39 &,- 286 & 147, & -,115 &,- 074 &,- 261 & ,019 & 286 &,- 226 & ,081 &,- 130 & ,034 &,- 037 & 126 &,- 467 &,- 844 & $.556^{a}$ \\
\hline
\end{tabular}


Tabel 6. Nilai akar ciri komponen utama berdasarkan analisis komponen utama

\begin{tabular}{|c|c|c|c|c|c|c|c|c|c|}
\hline \multirow[b]{2}{*}{ Komponen } & \multicolumn{3}{|c|}{ Akar Ciri } & \multicolumn{3}{|c|}{ Ekstraksi Akar Kuadrat } & \multicolumn{3}{|c|}{ Rotasi Akar Kuadrat } \\
\hline & Total & $\begin{array}{c}\% \\
\text { Keragaman }\end{array}$ & $\begin{array}{c}\text { Kumulatif } \\
\%\end{array}$ & Total & $\begin{array}{c}\% \\
\text { Keragaman }\end{array}$ & $\begin{array}{c}\text { Kumulatif } \\
\% \\
\end{array}$ & Total & $\begin{array}{c}\% \\
\text { Keragaman } \\
\end{array}$ & $\begin{array}{c}\text { Kumulatif } \\
\%\end{array}$ \\
\hline 1 & 3,664 & 28,183 & 28,183 & 3,664 & 28,183 & 28,183 & 2,729 & 20,992 & 20,992 \\
\hline 2 & 2,083 & 16,023 & 44,207 & 2,083 & 16,023 & 44,207 & 2,276 & 17,509 & 38,500 \\
\hline 3 & 1,627 & 12,516 & 56,722 & 1,627 & 12,516 & 56,722 & 1,831 & 14,085 & 52,586 \\
\hline 4 & 1,141 & 8,779 & 65,502 & 1,141 & 8,779 & 65,502 & 1,679 & 12,916 & 65,502 \\
\hline 5 & ,956 & 7,351 & 72,852 & & & & & & \\
\hline 6 & ,853 & 6,559 & 79,412 & & & & & & \\
\hline 7 & ,765 & 5,886 & 85,298 & & & & & & \\
\hline 8 & ,557 & 4,282 & 89,580 & & & & & & \\
\hline 9 & ,466 & 3,582 & 93,163 & & & & & & \\
\hline 10 & ,389 & 2,990 & 96,153 & & & & & & \\
\hline 11 & ,246 & 1,892 & 98,044 & & & & & & \\
\hline 12 & 180 & 1,386 & 99,431 & & & & & & \\
\hline 13 & 074 &, 569 & 100,000 & & & & & & \\
\hline
\end{tabular}

Berdasarkan analisis komponen utama terdapat empat komponen yang mempunyai akar ciri $>1$ (Tabel 6). Empat komponen tersebut merupakan hasil reduksi dari 13 peubah yang dapat menerangkan keragaman sebesar $65,50 \%$. Analisis data untuk mengelompokkan 30 jenis Begonia yang dipelajari digunakan tiga Komponen Utama (KU) yang dapat menjelaskan $56,72 \%$ dari variabilitas 13 peubah.

Tabel 7. Nilai vektor ciri tiga komponen utama berdasarkan analisis komponen utama

\begin{tabular}{llrrr}
\hline \multirow{2}{*}{ No } & & \multicolumn{3}{c}{ Komponen } \\
& & $\mathbf{1}$ & $\mathbf{2}$ & $\mathbf{3}$ \\
\hline 1 & Bentuk daun & $-0,156$ & $-0,312$ & $-0,374$ \\
2 & Pangkal daun & $-0,527$ & 0,331 & $-0,374$ \\
3 & Ujung daun & $-0,248$ & 0,341 & $\mathbf{0 , 5 3 4}$ \\
4 & Pinggiran daun & $-0,118$ & 0,269 & $\mathbf{0 , 6 6 8}$ \\
5 & Distribusi warna sekunder permukaan atas daun & 0,335 & $-0,772$ & 0,231 \\
6 & Pewarnaan pada pertulangan daun pada permukaan atas & 0,497 & 0,250 & 0,174 \\
7 & Warna pertulangan daun pada permukaan atas & $\mathbf{0 , 6 2 4}$ & $-0,273$ & 0,352 \\
8 & Warna primer permukaan bagian bawah daun & 0,019 & $-0,294$ & $\mathbf{0 , 6 2 6}$ \\
9 & Warna sekunder permukaan bagian bawah daun & $\mathbf{0 , 5 0 6}$ & $-0,173$ & $-0,163$ \\
10 & Panjang tangkai bunga/perbungaan & $\mathbf{0 , 7 3 0}$ & 0,245 & $-0,106$ \\
11 & Warna tangkai bunga/perbungaan & $\mathbf{0 , 7 2 6}$ & $-0,056$ & $-0,208$ \\
12 & Warna bunga jantan & $\mathbf{0 , 6 0 9}$ & $\mathbf{0 , 5 9 8}$ & $-0,039$ \\
13 & Warna bunga betina & $\mathbf{0 , 6 8 2}$ & $\mathbf{0 , 5 5 0}$ & 0,006 \\
\hline
\end{tabular}

Berdasarkan nilai vektor ciri (Tabel 7), komponen I terdiri atas enam peubah yaitu warna pertulangan daun pada permukaan atas, warna sekunder permukaan bagian bawah daun, panjang tangkai bunga/perbungaan, warna tangkai bunga/perbungaan, warna bunga jantan, dan warna bunga betina. Komponen II terdiri atas dua peubah yaitu warna bunga jantan dan warna bunga betina. Komponen III terdiri atas tiga peubah yaitu ujung daun, tepi daun, dan warna primer permukaan bagian bawah daun. Berdasarkan pengelompokan KU I dan KU II jenis Begonia dapat dikelompokan menjadi tujuh kelompok (Gambar 1). Berdasarkan pengelompokan KU I dan KU III, jenis Begonia dapat dikelompokan menjadi delapan kelompok (Gambar 2). Berdasarkan pengelompokan KU II dan KU III jenis Begonia dapat dikelompokan menjadi lima kelompok (Gambar 3). 


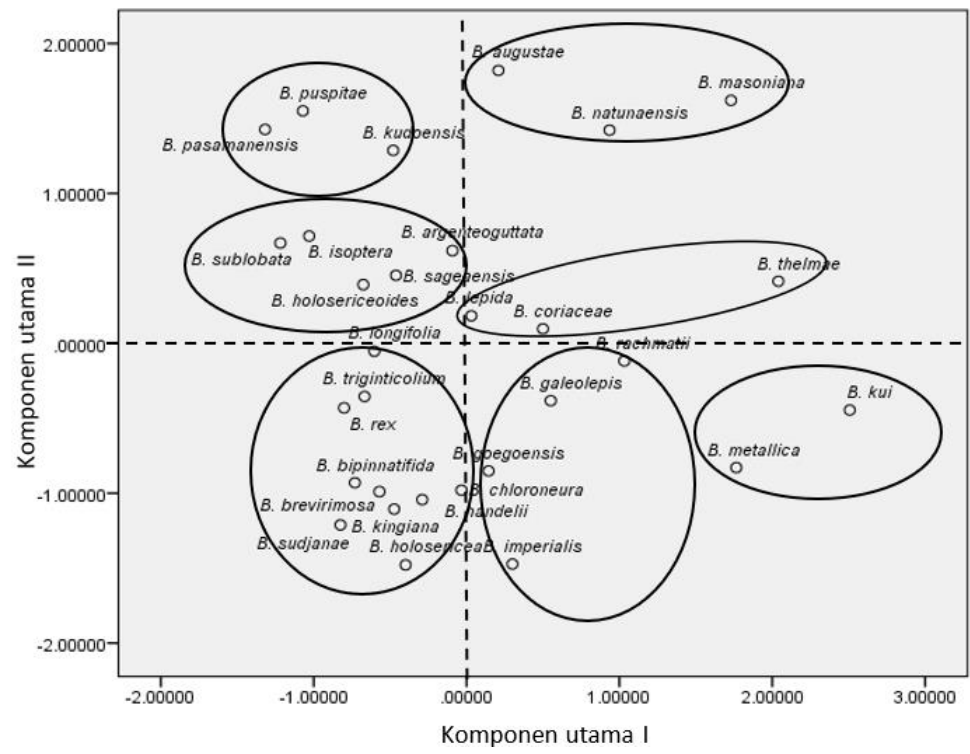

Gambar 1. Analisis komponen utama 30 jenis Begonia KU I dan KU II

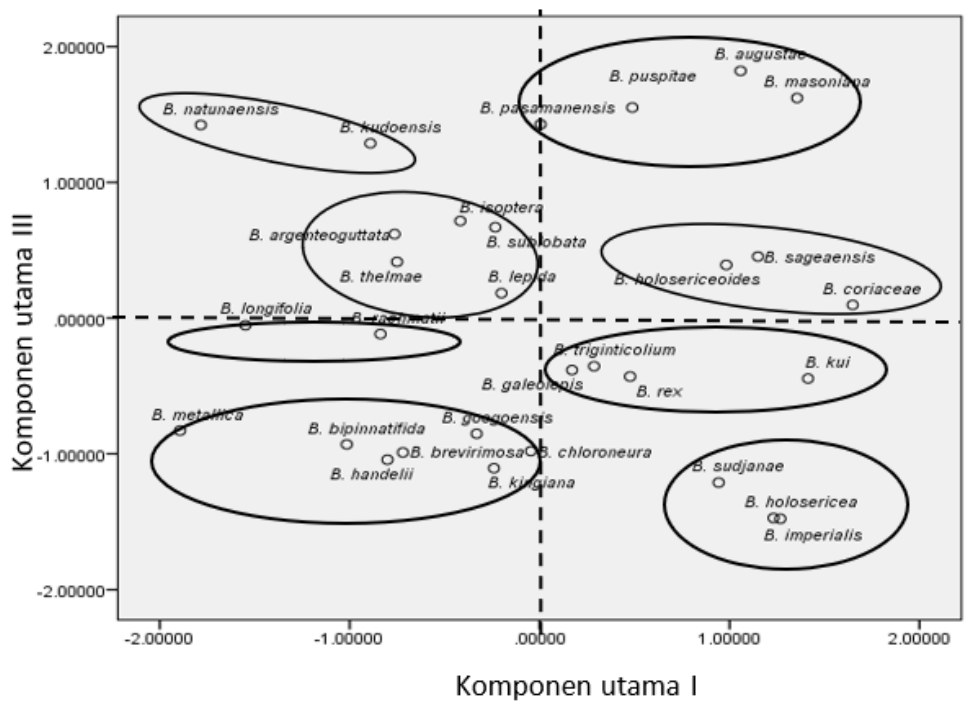

Gambar 2. Analisis komponen utama 30 jenis Begonia KU I dan KU III

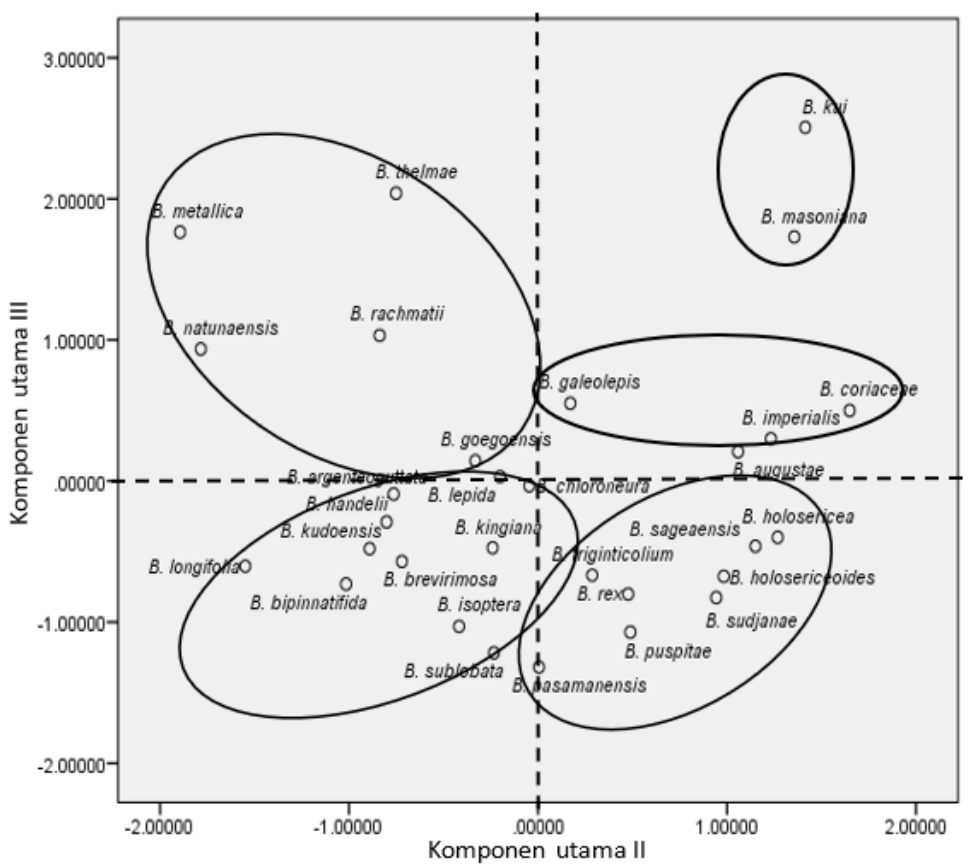

Gambar 3. Analisis komponen utama 30 jenis Begonia KU II dan KU III 
Salah satu kunci keberhasilan dari suatu program pemuliaan tanaman adalah pemilihan tetua yang tepat. Pemilihan tetua yang memiliki tingkat keragaman yang besar akan mempermudah pemulia untuk mendapatkan informasi mengenai pewarisan sifat untuk karakter penting pada suatu tanaman (Bertan et al. 2007; Istiqlal et al. 2019).

Berdasarkan hasil analisis gerombol (cluster analysis) yang dilakukan pada 30 jenis dengan 39 peubah menghasilkan dendrogram seperti ditunjukkan pada Gambar 4. Jenis Begonia dikelompokkan menjadi enam kelompok besar pada tingkat kemiripan $85 \%$ atau ketidakmiripan $15 \%$. Jenis-jenis yang mengelompok pada kelompok I terdiri atas 15 Jenis, yaitu B. kingiana, B. sudjanae, B. trigina, B. holosericea, B. holosericeoides, B. galeolepis, B. sublobata, B. sagaensis, B. lepida, B. rex, B. brevirimosa, B. chloroneura, B. kudoensis, $B$. goegoensis, dan $B$. handelii. Kelompok II terdiri atas $B$. pasamanensis $B$. puspitae, B. $x$ argenteoguttata, $B$. isoptera, dan B. longifolia. Kelompok III terdiri atas B. rachmatii. Kelompok IV terdiri atas $B$. natunaensis, $B$. thelmae dan B. metalica. Kelompok $V$ terdiri atas $B$. augustae dan B. coriacea. Kelompok VI terdiri atas $B$. kui dan B. masoniana, B. imperalis dan B. bipinnatifida. Pengelompokan jenis dengan menggunakan analisis gerombol telah digunakan oleh pemulia-pemulia untuk membatu proses pemilihan tetua yang akan digunakan dalam kegiatan hibridisasi selanjutnya. Metode pengelompokan memiliki tujuan untuk memisahkan jenis yang diamati dengan banyak subkelompok untuk mendapatkan homogenitas di dalamnya dan antara subkelompok yang terbentuk (Bertan et al. 2007).

Pemilihan tetua yang akan digunakan pada program selanjutnya juga dikombinasikan dengan informasi kuantititaf yang diperoleh.
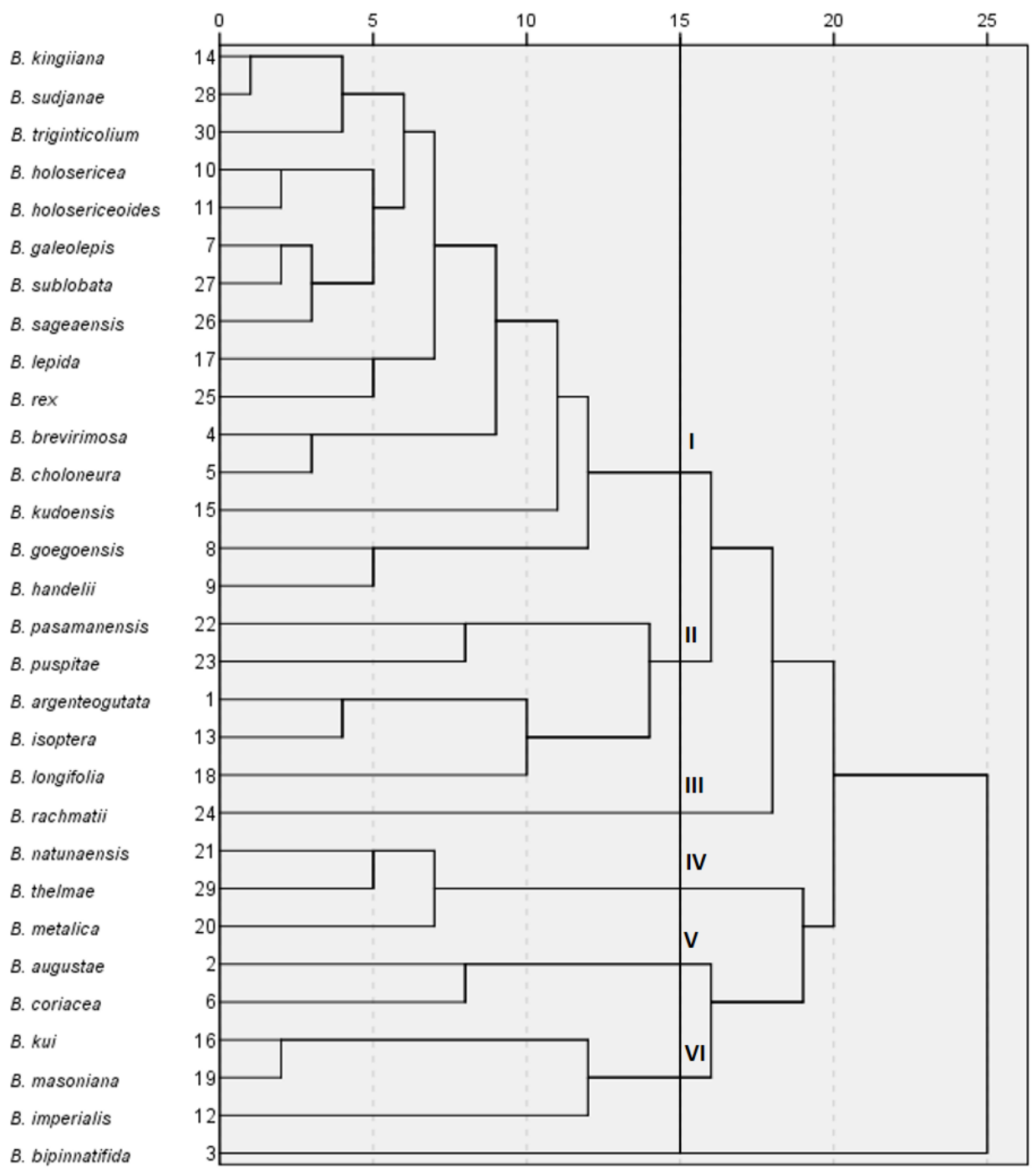

Gambar 4. Dendrogram hasil analisis gerombol 30 jenis Begonia 

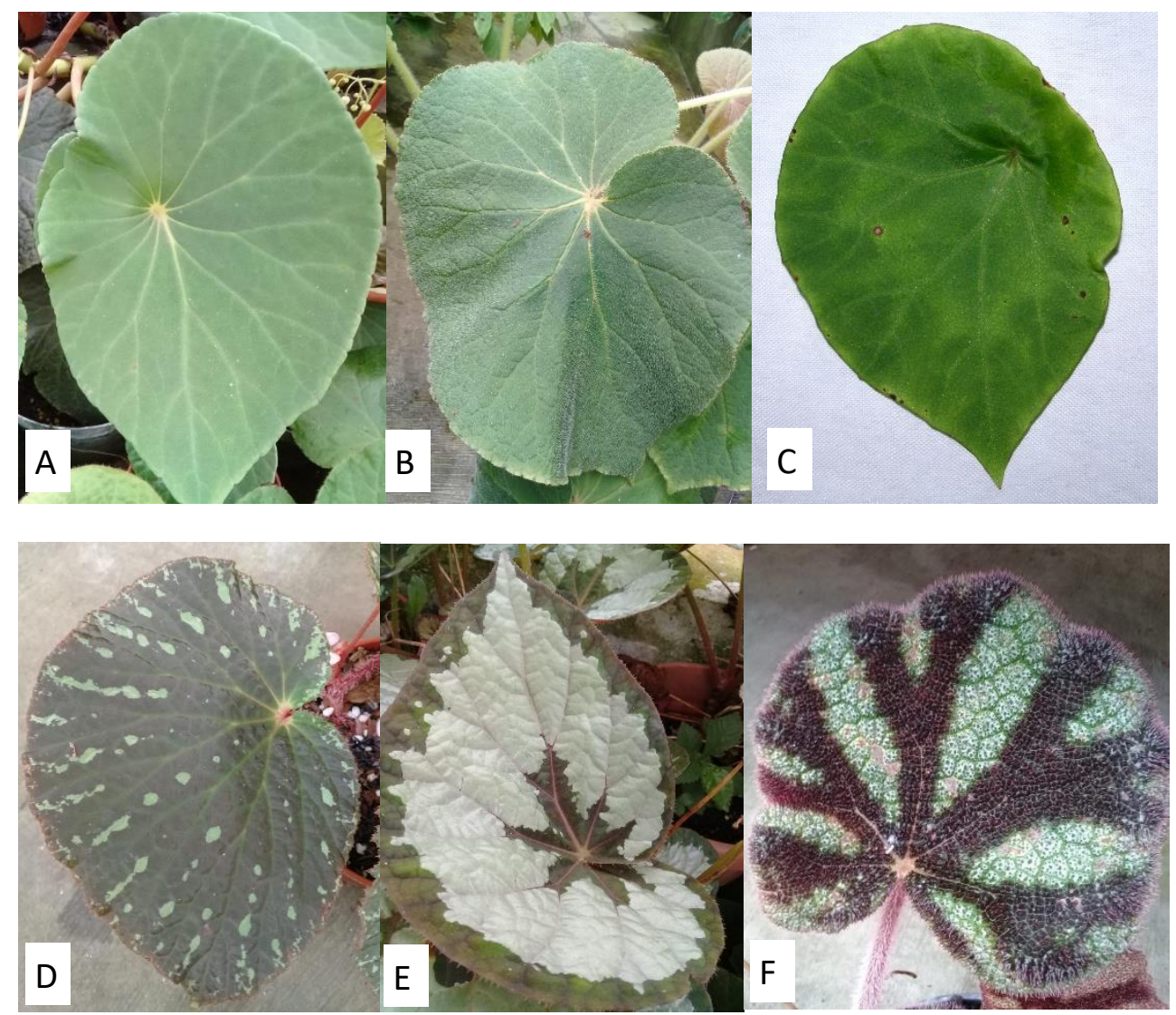

Gambar 5. Daun dari jenis Begonia yang direkomendasikan untuk program pemuliaan selanjutnya. (A) B. kudoensis, (B) B. puspitae, (C) B. coriacea, (D) B. holocericeoides, (E) B. rex, dan (F) B. masoniana.

Jenis Begonia yang direkomendasikan untuk digunakan dalam program pemuliaan selanjutnya, yaitu B. kudoensis, B. holocericeceoides, dan B. rex dari kelompok I; B. puspitae dari kelompok II; B. coriacea dari kelompok V; dan B. masoniana dari Kelompok VI (Gambar 5). Jenis-jenis tersebut dipilih karena berasal dari kelompok yang berbeda pada dendrogram yang dihasilkan. Berdasarkan klasifikasi taksonomi, B. coriacea, B. kudoensis, dan B. puspitae termasuk dalam seksi Jackia; B. holocericeceoides termasuk dalam seksi Petermannia; $B$. rex termasuk dalam seksi Platycentrum; dan B. masoniana termasuk dalam seksi Coelocentrum (Moonlight et al. 2018). Pemilihan jenis yang berada dalam satu kelompok atau mempunyai jarak genetik yang dekat akan memudahkan dalam proses persilangan dan pemilihan jenis dari kelompok yang berbeda atau jarak genetiknya jauh adalah cara untuk memprediksi mendapatkan keragaman yang luas pada kombinasi hibrida yang akan dihasilkan (Bertan et al. 2007).
Berdasarkan hasil penelitian sebelumnya, beberapa jenis Begonia alam koleksi KRB dan Kebun Raya Eka Karya Bali yang mempunyai karakteristik morfologi daun (bentuk, warna, tekstur) menarik dan dapat dinikmati sebagai tanaman hias tanpa melalui tahapan hibridisasi antara lain B. holosericeoides Ardi \& D.C. Thomas, B. puspitae Ardi, dan B. sudjanae C.A. Jansson. Jenis tersebut berpotensi untuk dikembangkan sebagai tanaman hias daun dan dapat dijadikan induk silangan untuk merakit varietas unggul Begonia berdaun indah (Siregar et al. 2018). Program pemuliaan Begonia di KRB ini merujuk pada klasifikasi pemuliaan Begonia berdaun indah (Hvoslef-Eide \& Munster 2006). B. rex dan B. masoniana diharapkan dapat menghasilkan varietas baru dengan memperbaiki karakter Begonia yang berasal dari Indonesia seperti B. puspitae, B. kudoensis, B. holocericeoides, dan $B$. coriacea yang direkomendasikan digunakan pada program pemuliaan. Hvoslef-Eide \& Munster (2006) menjelaskan bahwa $B$. rex ditanam terutama karena berdaun indah. Jenis ini memiliki batang yang membentuk rizhome (rhizomatous), daun 
besar (hingga $30 \times 20 \mathrm{~cm}$ ), bunga kecil, dan berwarna pink pucat. Kultivar $B$. rex telah dirakit dengan menyilangkan kelompok jenis $B$. rex Cultorum dengan jenis Begonia lainnya. Banyak varietas Begonia berdaun indah telah ditanam dari galur keturunan B. rex Cultorum. Kultivar dan hibrida Begonia berdaun indah dikumpulkan dengan nama $B$. rex, misalnya $B$. masoniana yang lebih dikenal sebagai $B$. 'Iron cross', tanaman ini dikembangkan karena daunnya indah bermotif merah kecokelatan. Popularitas B. rex dan Begonia rhizomatous lainnya merupakan kelompok Begonia yang paling besar.

\section{KESIMPULAN}

Hasil analisis ragam menunjukkan bahwa jenis Begonia berpengaruh nyata pada semua karakter vegetatif. Hasil penelitian menunjukkan bahwa analisis komponen utama pada 30 jenis Begonia terdapat empat komponen yang mempunyai akar ciri >1 yang merupakan hasil reduksi dari 13 peubah yang dapat menerangkan keragaman sebesar 65,50\%. Berdasarkan nilai vektor, ciri komponen I terdiri atas tujuh peubah yaitu warna pertulangan daun pada permukaan atas, warna sekunder permukaan bagian bawah daun, warna tangkai daun, panjang tangkai bunga/ perbungaan, warna tangkai bunga/perbungaan, warna bunga jantan, dan warna bunga betina. Komponen II terdiri atas satu peubah yaitu warna bunga jantan. Komponen III terdiri atas tiga peubah, yaitu ujung daun, pinggiran daun, dan warna primer permukaan bagian bawah daun. Jenis Begonia dikelompokkan menjadi enam kelompok besar pada tingkat kemiripan $85 \%$. Dari hasil penelitian ini, Begonia yang akan direkomendasikan untuk program pemuliaan yaitu $B$. holocericeoides, $B$. kudoensis, B. rex, B. puspitae, B. coriacea, dan B. masoniana.

\section{UCAPAN TERIMA KASIH}

Penelitian ini didanai oleh DIPA Pusat Penelitian Konservasi Tumbuhan dan Kebun RayaLIPI melalui kegiatan In house research tahun 2019. Ucapan terima kasih disampaikan kepada Kepala Pusat Penelitian Konservasi Tumbuhan dan Kebun Raya-LIPI, rekan-rekan di Unit Kerja Pembibitan Kebun Raya Bogor, terutama kepada Sdr. Wisnu H. Ardi atas sharing ilmunya, Akbar Taufik dan rekan- rekan yang membantu dalam pemeliharaan koleksi dan rekan peneliti yang telah membawa koleksi Begonia dari hasil eksplorasi di hutan seluruh Indonesia.

\section{DAFTAR PUSTAKA}

Bertan I, de Carvalho FIF, de Oliveira AC. 2007. Parental selection strategies in plant breeding programs. Journal of Crop Science and Biotechnology 10(4): 211-222.

Chen YM, Mii M. 2012. Interspecific hybridization of Begonia semperflorens (section Begonia) with $B$. pearcei (section Eupetalum) for introducing yellow flower color. Plant Biotechnology 29: 77-85.

Chung KF, Leong WC, Rubite RR, Repin R, Kiew R, Liu $\mathrm{Y}$, Peng $\mathrm{Cl}$. 2014. Phylogenetic analyses of Begonia sect. Coelocentrum and allied limestone species of China shed light on the evolution of Sino-Vietnamese karst flora. Botanical Studies 55: 1-15. http://www.asbotanicalstudies.com/ content/55/1/1.

Ciolakowska AM, Ramanna MS, ter Laak WA, van Tuyl JM. 2010. Genome composition of 'Elatior'-begonias hybrids analyzed by genomic in situ hybridization. Euphytica 171: 273-282.

Dewitte AAD, Twyford DC, Thomas CA, Kidner J, Van Huylenbroeck. 2011. The origin of diversity in Begonia: Genome dynamism, population processes and phylogenetic patterns, the dynamical processes of biodiversity - Case studies of evolution and spatial distribution, PhD. Oscar Grillo (Ed.). InTech, Available from: http://www. intechopen.com/books/ the-dynamical-processes-of-

biodiversitycase-studies-of-evolution-andspatial-distribution/the-origin-of-diversityin-begonia-genome-dynamismpopulationprocesses-and-phylogenetic-patterns. (accessed 11 February 2020).

Girmansyah D. 2008. A taxonomic study of Bali and Lombok Begonia (Begoniaceae). Reinwardtia 12(5): $419-434$.

Harrison N, Harrison RJ, Kidner CA. 2016. Comparative analysis of Begonia plastid genomes and their utility for species-level phylogenetics. PLoS ONE 11(4): e0153248. doi:10.1371/journal. pone.0153248. 
Horn W. 2004. The patterns of evolution and ornamental plant breeding. Proceeding $21^{\text {st }}$ IS on Breeding Ornamentals, Part II. Eds: Forkmann G, Michaelis S. Acta Hort 651: 1931.

Hughes M, Miller AG. 2002. A new endemic species of Begonia (Begoniaceae) from the Socotra archipelago. Edinburgh Journal of Botany 59(2): 273-281.

Hughes M. 2008. An annotated checklist of Southeast Asian Begonia. Royal Botanic Gardens Edinburgh, Edinburgh.

Hughes M, Girmansyah D, Ardi WH, Nurainas. 2009. Seven new species of Begonia from Sumatra. Gardens' Bulletin Singapore 61(1): 29-44.

Hughes M, Peng Cl. 2018. 300 Species portraits Asian Begonia. Published of De. Cecilia Koo Botanic Conservation and Environmental Protection Foundation Conservation Centre (KBCC Press), Taipei.

Hvoslef-Eide AK, Munster C. 2006. Chapter 9. Begonia: History and breeding. In: Anderson NO (Ed.). Flower breeding and genetics issues, challenges and opportunities for the $21^{\text {st }}$ century. University of Minnesota, St. Paul, Minnesota.

Istiqlal MRA, Syukur M, Wahyu Y. 2019. Keragaman genetik karakter kuantitatif pada tanaman Cabai (Capsicum annuum L.). Comm. Horticulturae Journal 3(1):6-12. DOI: http://dx.doi.org/10.29244/chj.3.1.6-12.

Kementerian Pertanian Republik Indonesia, Pusat Perlindungan Varietas Tanaman. 2014. Buku panduan pelaksanaan uji (PPU) BUSS. Kebaruan, keunikan, keseragaman dan kestabilan "Guidelines for the conduct of test for distinctness, uniformity and stability Begonia. Kementerian Pertanian Republik Indonesia, Jakarta. (tidak dipublikasikan).

Kiew R. 2005. Begonias of Peninsular Malaysia. National History Publication and Singapore Botanic Gardens National Parks Broad, Singapore.

Krempin J. 1993. Know your Begonias. Krempin Books 25 Beverley Crescent Broadbeach Waters, Queensland.

Kroon GH. 1993. Breeding research in Begonia. Acta Horticulture 337: 53-58.

Lucas G, Synge H. 1978. The IUCN plant red data book. The World Wildlife Fund, The
Herbarium Royal Botanic Gardens, Kew, Richmond, Surrey.

Mattjik AA, Sumertajaya IM. 2006. Perancangan percobaan dengan aplikasi SAS dan Minitab. IPB Press, Bogor.

Mattjik AA, Sumertajaya IM. 2011. Sidik peubah ganda dengan menggunakan SAS. IPB Press, Bogor.

Moonlight PW, Ardi WH, Padilla LA, Chung KF, Fuller $D$, Girmansyah $D$, Hollands R, Jara-Muñoz $A$, Kiew R, Leong WC, Liu Y, Mahardika A, Marasinghe LDK, O'Connor $\mathrm{M}$, Peng $\mathrm{Cl}$, Pérez AJ, Phutthai T, Pullan M, Rajbhandary S, Reynel C, Rubite RR, Sang J, Scherberich D, Shui YM, Tebbitt MC, Thomas DC, Wilson HP, Zaini NH, Hughes M. 2018. Dividing and conquering the fastest-growing genus: Towards a natural sectional classification of the mega-diverse genus Begonia (Begoniaceae). Taxon 67(2): 267-323.

Rajbhandary S, Hughes M, Phutthai T, Thomas DC, Shrestha KK. 2011. Asian Begonia: out of Africa via the Himalayas? Gardens' Bulletin Singapore 63(1 \& 2): 277-286.

Siregar HM, Wahyuni S, Ardi WH. 2015. Pendugaan nilai heritabilitas dan heterosis karakter vegetatif pada generasi F1 hasil persilangan interspesifik Begonia natunaensis C. W. Lin \& C.-I Peng x Begonia puspitae Ardi. Prosiding Seminar Nasional Hasil Penelitian Unggulan Bidang Pangan Nabati: Bioresources untuk Pembangunan Ekonomi Hijau. Pusat Penelitian Bioteknologi-LIPI, Bogor. hal. 555564.

Siregar HM, Siregar M. 2013. Seratus jenis Begonia eksotik kebun raya siap bersaing mendukung bisnis florikultura di masa yang akan datang. Prosiding Seminar Inovasi Florikultura Nasional. Pusat Penelitian dan Pengembangan Hortikultura, Kementerian Pertanian, Jakarta. hal. 91-98.

Siregar HM, Wahyuni S, Ardaka IM. 2018. Karakterisasi morfologi daun Begonia alam (Begoniaceae): Prospek pengembangan koleksi tanaman hias daun di Kebun Raya Indonesia. Jurnal Biologi Indonesia 14(2): 201-211.

Siregar HM, Wisnu H. Ardi. 2015. Sertifikasi PVT Begonia "Lovely Jo" Persilangan Interspesifik B. puspitae Ardi X B. pasamanensis M. Hughes. Prosiding Seminar Nasional Masyarakat Biodiversitas Indonesia 1(3): 484-489. 
Sleper DA, Poehlman JM. 2006. Breeding field crops. Fifth Edition. Blackwell Publishing, Oxford.

Syukur M, Sujiprihati S, Yunianti R. 2012. Teknik pemuliaan tanaman. (1). Penebar Swadaya, Jakarta.

Tebbitt MC. 2005. Begonias, Cultivation, Identification, and Natural History. Timber Press, Oregon.

Thomas DC, Hughes M, Phutthai T, Ardi WH, Rajbhandary S, Rubite R, Twyford AD, Richardson JE. 2012. West to east dispersal and subsequent rapid diversification of the mega-diverse genus Begonia (Begoniaceae) in the Malesian archipelago. Journal of Biogeography 39(1): 98-113. http://dx. doi.org/10.1111/j.1365-2699.2011.02596.x

UPOV. 2007. International union for the protection of new varieties of plants (UPOV). Elatior Begonia UPOV Code: Begonia - HIE Begonia $x$ hiemalis Fotsch. Guidelines for the conduct of test for distinctness, uniformity and stability. Geneva.

Yunianti R, Sastrosumarjo S, Sujiprihati S, Surahman M, Hidayat SH. 2007. Ketahanan 22 genotipe cabai (Capsicum spp.) terhadap Phytophthora capsici leonian dan keragaman genetiknya. Buletin Agronomi 35: 103-111. 